\title{
Hubungan Berat Badan Lahir (BBL) Bayi dan Perilaku Asi Eksklusif Terhadap Stunting Pada Balita
}

\author{
Nadia Maulidah', Anggray Duvita Wahyani2* \\ 1,2 Program Studi Gizi, Fakultas Ilmu Kesehatan, Universitas Muhadi Setiabudi Brebes, Indonesia \\ Email correspondence : anggray@umus.ac.id
}

\begin{abstract}
ABSTRAK
Stunting merupakan salah satu indikasi buruknya status gizi pada anak. Prevalensi stunting di Jawa Tengah pada tahun 2017 28,5\%.Dukuhmaja merupakan salah satu desa yang berada di wilayah kerja puskesmas Jatirokeh, Survey yang dilakukan di 7 posyandu yang ada di desa Dukuhmaja didapatkan dari 330 balita yang diukur terdapat 39 yang mengalami stunting. Hasil wawancara menunjukan bahwa semuanya lahir dengan berat badan lahir normal yaitu diatas 2500 gram, namun perilaku ASI Eksklusif di desa Dukuhmaja masih sangat rendah, dari 70 balita hanya terdapat 2 balita yang mendapatkan ASI Eksklusif. Jenis penelitian analitik kuantitatif dengan desain cross sectional. Populasi berjumlah 330 orang balita, sampel 70 responden dengan teknik accidental sampling. analisis data secara bivariat. Hasil penelitian diperoleh sebanyak 13 orang balita mengalami stunting, tidak ada balita yang lahir dengan berat badan lahir rendah (BBLR), dan hanya 2 balita yang mendapatkan ASI Eksklusif. Tidak ada hubungan yang signifikan antara berat badan lahir rendah (BBLR) dengan kejadian stunting diamana $p$ value >0,05 yaitu 0.995 dan juga tidak ada hubungan antara perilaku pemberian ASI Eksklusif dengan kejadian stunting dengan $p$ value > 0,05 yaitu 0.25. dapat disimpulkan bahwa tidak ada hubungan antara BBLR dan ASI Eksklusif dengan kejadian stunting.
\end{abstract}

Kata kunci : ASI Eksklusif, BBLR, Stunting.

\begin{abstract}
Stunting is one indication of poor nutritional status in children. The prevalence of stunting in Central Java in $201728.5 \%$. Dukuhmaja is one of the villages located in the area of puskesmas work in Jatirokeh, Survey conducted in 7 Posyandu in the village of Dukuhmaja obtained from 330 toddlers that measured there are 39 who are stunting. The interview showed that everything was born with normal birth weight of above 2500 grams, but the exclusive breast milk behavior in Dukuhmaja village is still very low, from 70 toddlers There are only 2 infants who get exclusive breast milk. Types of quantitative analytic research with cross sectional design. The population amounted to 330 toddlers, samples of 70 respondents with accidental sampling techniques. Bivariate data analysis. The results of the study gained as many as 13 toddlers are stunted, no toddlers are born with low birth weight (BBLR), and only 2 toddlers who get exclusive breast milk. There is no significant link between low birth weight $(B B L R)$ with a stunting event of where P value $>0.05$ which is 0995 and also no link between exclusive breast feeding behaviour with stunting events with $P$ value $>0.05$ i.e. 0.25. Can be concluded that there is no link between the BBLR and the exclusive ASI with the stunting event.
\end{abstract}

Kata kunci : Exclusive breastfeeding, Low birth weight (BBLR), Stunting.

\section{PENDAHULUAN}

Stunting merupakan salah satu permasalahan gizi yang terjadi di Indonesia. Dampak stunting tidak hanya dirasakan oleh individu yang mengalaminya, tetapi juga berdampak terhadap roda perekonomian dan pembangunan bangsa. Hal ini karena sumberdaya manusia stunting memilliki kualitas lebih rendah dibandingkan sumberdaya manusia normal. Stunting (balita pendek) ketika usia balita pada umumnya sering tidak disadari oleh keluarga dan setelah 2 tahun baru terlihat dan berdampak pada kemampuan kognitif dan produktivitas jangka panjang, bahkan bisa berdampak pada kematian[1]

Informasi Artikel:

Submitted: Juni 2020, Accepted: Agustus 20xx, Published: Agustus 2020

ISSN: 2716-0084 (media online), Website: http://jurnal.umus.ac.id/index.php/jigk 
Poporsi status gizi sangat pendek dan pendek turun dari 37,2\% (Riskesdas 2013) menjadi 30,8\% (Riskesdas 2018), prevalensi stunting bayi berusia dibawah lima tahun (Balita) Jawa Tengah mencapai 28,5\% menduduki peringkat ke 24 dari 34 provinsi (Pantauan Status Gizi 2017), Kabupaten Brebes merupakan salah satu kabupaten di provinsi jawa tengah yang masuk dala 1000 kabupaten prioritas stunting dengan prevalensi 21,66\% pada tahun 2016 dan meningkat menjadi 28,52\% pada tahun 2017 (Hasil Pemantauan Status Gizi 2015-2017).

Puskesmas Jatirokeh merupakan salah satu dari 38 puskesmas yang ada di Kabupaten Brebes, berdasarkan data dari Dinas Kesehatan Kabupaten Brebes 2018 Pukesmas Jatirokeh berada dalam urutan nomer 2 Puskemas dengan prevalensi stunting mencapai 178 balita (69 balita sangat pendek dan 109 balita pendek). Jika dilihat dari umur balita, ternyata kejadian stunting banyak terdapat pada usia 12 hinggga 59 bulan. Padahal teori menjelaskan bahwa $90 \%$ pertumbuhan otak manusia terjadi sejak janin sampai sebelum anak berusia lima tahun. Bahkan, $70 \%$ pertumbuhan otak itu terjadi dibawah usia 2 tahun[2]. Proses pertumbuhan seperti ini tidak dijumpai di periode-periode usia lainnya. Oleh sebab itu periode ini dijuluki masa emas atau periode kritis [3].

Masa baduta disebut sebagai 'masa kritis'. Salah satu indikator masa kritis adalah ketika anak lahir dengan BBLR[4]. Salah satu faktor risiko yang mempengaruhi kejadian stunting pada anak balita adalah riwayat berat badan lahir rendah (BBLR)[5] akibatnya pertumbuhan bayi BBLR akan terganggu, bila keadaan ini berlanjut dengan pemberian makanan yang tidak mencukupi, sering mengalami infeksi, dan perawatan kesehatan yang tidak baik dapat menyebabkan anak stunting. Namun secara tidak langsungkejadian stunting juga dipengaruhi oleh faktor sosial ekonomi, seperti tingkat pendidikan, pendapatan, dan jumlah anggota rumah tangga[6].

Balita yang sering mengalami sakit akan berpengaruh pada pertumbuhan karena adanya sakit akan diikuti nafsu makan menurun [7] pemberian ASI eksklusif dapat menurunkan resiko kejadian stunting karena ASI mengandung antibodi dan kandungan kalsium pada ASI mempunyai bioavailabilitas yang tinggi sehingga dapat diserap dengan optimal terutama dalam fungsi pembentukan tulang[8].

\section{BAHAN DAN METODE}

Jenis penelitian ini adalah observasional dengan desain Cross-sectional (Ariani, 2014). Populasi dalam penelitian ini adalah seluruh ibu yang memuliki balita yang melakukan penimbangan bulan februari 2019 di seluruh posyandu desa Dukuhmaja melalui program PSG (pemantauan status gizi) dengan jumlah 330 balita. Sampel diambil dengan metode non random samplilng melalui teknik accidental sampling sebanyak 70 orang balita. Variabel yang diteliti dalam penelitian ini yaitu stunding sebagai variabel dependent; berat badan lahir rendah (BBLR) dan ASI Eksklusif sebagai variabel independent. Analisis data secara bivariat untuk melihat hubungan antara berat badan lahir rendah (BBLR) dan pemberian ASI esklusif dengan stunting pada balita di desa Dukuhmaja.

\section{HASIL DAN PEMBAHASAN}

Penelitian ini dilaksankan di desa Dukuhmaja, kecamatan Songgom, kabupaten Brebes. Hasil data yang didapat diproses dan diolah dengan sistem komputerisasi dan disajikan dalam bentuk analisis bivariat, analisis bivariat dilakukan untuk melihat hubungan antara variabel independen dengan variabel dependen. Dalam hal ini termasuk variabel independen adalah berat badan lahir rendah (BBLR) dan ASI eksklusif sedangkan variabel dependen adalah stunting. Analisis hubungan BBLR dengan stunting dapat dilihat pada Tabel 1. 
Tabel 1. Hubungan BBLR dengan Stunting di desa Dukuhmaja kecamatan Songgom kabupaten Brebes Jawa Tengah.

\begin{tabular}{lllll}
\hline & & $\begin{array}{l}\text { Pengukuran } \\
\text { Indeks TB/U }\end{array}$ & $\begin{array}{l}\text { Berat } \\
\text { Lahir }\end{array}$ & Badan \\
\hline Pengukuran Indeks TB/U & Pearson Correlation & 1 & .000 & \\
& Sig (2-tailed) & & .995 & \\
& $\mathrm{~N}$ & 70 & 70 \\
\hline Berat Badan Lahir & Pearson correlation & .000 & 1 \\
& Sig (2-tailed) & .995 & & \\
& $\mathrm{~N}$ & 70 & 70 \\
\hline
\end{tabular}

Dari 70 data balita berusia 7-59 bulan dari 7 posyandu yang ada di desa Dukuhmaja tidak ada yang lahir dengan berat badan rendah (BBLR). Berdasarkan tabel.1 dari hasil corelasi pearson deperoleh nilai signifikasi $0.9995>0.5$, maka dapat disimpulkan tidak terdapat korelasi yang signifikan antara pengukuran indeks TB/U dengan Berat badan lahir di desa Dukuhmaja. Berat badan lahir rendah atau sering disebut dengan BBLR adalah bayi dengan berat badan lahir kurang dari 2500 gram (Saraswati \& Sumarmo 1998). Analisis hubungan ASI Eksklusif dengan stunting dapat dilihat pada tabel 2 .

Tabel 2. Hubungan ASI Eksklusif dengan Stunting di desa Dukuhmaja.

\begin{tabular}{llll}
\hline & & $\begin{array}{l}\text { Pengukuran } \\
\text { Indeks TB/U }\end{array}$ & $\begin{array}{l}\text { Perilaku } \\
\text { Eksklusif }\end{array}$ \\
\hline Pengukuran indeks TB/U & Pearson correlation & 1 & 0.139 \\
& Sig (2-tailed) & & 0.253 \\
& $\mathrm{~N}$ & 70 & 70 \\
\hline Perilaku ASI Eksklusif & Pearson correlation & 0.139 & 1 \\
& Sig (2 tailed) & 0.253 & \\
& $\mathrm{~N}$ & 70 & 70 \\
\hline
\end{tabular}

Dari 70 data balita berusia 7-59 bulan hanya terdapat 2 balita yang mendapatkan ASI Eksklusif. Berdasarkan tabel.2 hasil korelasi pearson di peroleh p-value $0.25>0.5$, maka dapat disimpulkan tidak terdapat korelasi antara perilaku ASI Ekslusif dengan kejadian stunting pada balita didesa Dukuhmaja. ASI merupakan makanan yang paling baik untuk bayi segera setelah lahir. Menurut WHO ASI Eksklusif adalah pemberian ASI saja Pada bayi sampai usia 6 bulan tanpa tambahan cairan ataupun makanan lain. ASI dapat diberikan sampai bayi berusia 2 tahun [9]

\section{KESIMPULAN}

Total 70 bayi yang lahir dengan berat badan lahir rendah (BBLR) hanya 2 balita yang diberikan ASI Eksklusif. Balita yang mengalami stunting sebanyak 13 balita. Hasil penelitian memperlihatkan bahwa tidak ada hubungan antara berat badan lahir rendah (BBLR) dengan kejadian stunting pada balita di desa Dukuhmaja dan juga tidak terdapat hubungan yang signifikan antara perilaku ASI Eksklusif dengan kejadian stunting di desa Dukuhmaja di kecamatan Songgom kabupaten Brebes.

\section{DAFTAR PUSTAKA}

[1] Z. Oktarina and T. Sudiarti, "FAKTOR RISIKO STUNTING PADA BALITA (24-59 BULAN) DI SUMATERA," J. Gizi dan Pangan, 2014, doi: 10.25182/jgp.2013.8.3.177180.

[2] F. O. Aridiyah, N. Rohmawati, and M. Ririanty, "Faktor-faktor yang Mempengaruhi Kejadian Stunting Pada Anak Balita di Wilayah Pedesaan dan Perkotaan (The Factor Affecting Stunting on Toddlers in Rural and Urban Areas)," e-Jurnal Pustaka Kesehat., vol. 3, no. 1, pp. 163-170, 2015, [Online]. Available: 
http://jurnal.unej.ac.id/index.php/JPK/article/download/2520/2029.

[3] Almatsier, Jakarta: Penerbit PT Gramedia Pustaka Utama. Baliwati. 2011.

[4] A. Rahayu, F. Yulidasari, A. O. Putri, and F. Rahman, "Riwayat Berat Badan Lahir dengan Kejadian Stunting pada Anak Usia Bawah Dua Tahun,” Kesmas Natl. Public Heal. J., 2015, doi: 10.21109/kesmas.v10i2.882.

[5] A. Proverawati and C. Ismawati, "BBLR (Berat Badan Lahir Rendah)," Yogyakarta, Nuha Med., 2010.

[6] M. A. Siregar, "Pemberian ASI Eksklusif dan Faktor-faktor yang Mempengaruhi," Gizi, 2014.

[7] M. K. Malde, L. Zerihun, K. Bjorvatn, and K. Julshamn, "Intake of iron, zinc and iodine in 28 ethiopian children living in wonji shoa sugar estate, assessed by duplicate portion technique," Sci. Res. Essays, 2010.

[8] M. Mahmud, "GAMBARAN PENGETAHUAN IBU TENTANG ZAT GIZI, TINGKAT KONSUMSI DAN STATUS GIZI BALITA DIPOSYANDU ASOKA PUSKESMAS TULEHU ...," Glob. Heal. Sci., 2019.

[9] E. Saraswati and I. Sumarno, "RISIKO IBU HAMIL KURANG ENERGI KRONIS (KEK) DAN ANEMIA UNTUK MELAHIRKAN BAYI DENGAN BERAT BADAN LAHIR RENDAH (BBLR),” Jurnal Penelitian Gizi dan Makanan. 1998. 